\title{
Medieval Religious Officials in Geoffrey Chaucer's Prologue to Canterbury Tales
}

\author{
Purwarno ${ }^{1}$, Sri Chairani ${ }^{2}$, Andang Suhendi ${ }^{1}$, and Susi Ekalestari ${ }^{1}$ \\ ${ }^{1}$ Universitas Islam Sumatera Utara (UISU), Medan, Indonesia \\ ${ }^{2}$ Islamic University of Kuantan Singingi (UNIKS), Riau, Indonesia
}

\section{Abstract}

Chaucer is a great humanist who gently unmasks the roguery, foolishness and corruption of the medieval religious officials in Geofrey Chaucer's Prologue to Canterbury Tales withour malice, spite or animosity. His attitude is that of benevolence and tolerance, even his satire is in the form of tender shafts of irony, which neither hurt nor destroy. He gives us a direct transcription of reality and a true picture of the medieval social condition as it actually lived in the age in most familiar aspects in his masterpiece work, The Canterbury Tales. He uses humour, irony, exaggeration and ridicule to satirize the medieval religious officials' follies and foibles. The research

Corresponding Author:

Purwarno

purwarno@sastra.uisu.ac.id

Received: 1 July 2019

Accepted: 18 July 2019

Published: 31 July 2019

Publishing services provided by Knowledge E

(c) Purwarno et al. This article is distributed under the terms of the Creative Commons.

Attribution License, which permits unrestricted use and redistribution provided that the original author and source are credited.

Selection and Peer-review under the responsibility of the AICLL 2019 Conference Committee. focuses on the seven medieval religious officials by the name eof the Prioress, the Monk, the Friar, the Clerk of Oxford, the Parson, the Summoner, and the Pardoner. This research aims at revealing the follies, the absurdities, the monetary greed, the hypocrisy, and, on the whole, the irreligious natures of these men of religion. The method used in this research is descriptive qualitative proposed by Creswell (2014). The research result shows that the religious characters of his times are portrayed in a most unfavourable light. The ecclesiastical characters that are favourably portrayed, and for whom Chaucer admires are the Clerk and the Parson. Chaucer has nothing to satirize for them but praise, while the other characters belonging to the church are ridiculed and satirized. They are not only most worldly-minded but also dishonest, immoral, and corrupt.

Keywords: Middle Age, medieval society, ecclesiastical characters, medieval religious officials, irony, satire.

\section{Introduction}

The Age of Chaucer covers the period from 1340-1400. The principal events, trends, and movements of this age in the political, economic, social, religious, and literary spheres are important for a proper understanding of the background of Chaucer's life and work.

The fourteenth century is dominated by Chaucer, the great poet of the age. So, it is also labeled as the Age of Chaucer. The fourteenth century is remarkable historically for the decline of feudalism (organized by the Normans), for the growth of the English national spirit during the wars with France, for the prominence of the House of Commons, 
and for the growing power of the labouring classes, who had theretofore been in a condition hardly above that of slavery. It was an age of restlessness; amid the ferment (state of excitement) of new life that Chaucer lived and wrote. Old things and new appear side by side upon his pages, and in his poetry we can study the essential spirit, both of the age that was passing, and of the age that was to come.

\section{Literature Review}

Literature reflects the trends of the times in which it is produced and there is always a towering literary artist who becomes the mouthpiece of his age and gives expression to its hopes and aspirations, its fads and fetishes, its fears and doubts, its prosperity or poverty and its enterprise in his works. Geoffrey Chaucer symbolizes the Middle Age. He stands in much the same relation to the life of his time as Pope does to the earlier phases of the eighteenth century, the Age of Neoclassicism, and Tennyson to the Victorian era in the later nineteenth century; and his place in English Literature is even more important than theirs.

So far as religious belief is concerned, Pope was not a representative of his age. He was a Roman Catholic whereas the majority of Englishmen in his age were Protestants, with a fair sprinkling of Puritans among them. However, Pope never asserts his religion anywhere in his work. He faithfully represents his Age, its social, intellectual life and literary tendencies in the poems such as "The Rape of the Lock", "Dunciad", "Essay on Man", and "Essay on Criticism". In "The Rape of the Lock", Pope satirically portrays the frivolous pursuits and affected life of the upper-class ladies of his age in the person and activities of Belinda. "The Essay on Man" is, likewise, an attempt to present the philosophical and intellectual principles of his Age. In the "Dunciad", Pope lets loose the floodgates of scurrilous satire attacking the political strife of the age and the low moral standards to which the wits had fallen in those days. Like Pope, Tennyson was equally the mouthpiece of the Victorian society, and represented the ideas, traditions, hopes and aspirations of the people. He reflected the fancies and sentiments of the Victorian England. In the "Princes", Tennyson associates himself with the suffragist movement of his time and makes a plea for the education and better placement of woman in society. In "Locksley Hall of 1842", he effectively presents the restless spirit of 'young England' and the optimistic belief of the age in science, commerce and the progress of mankind; while its sequel "Locksley Hall Sixty Years After" (1886) shows the revulsion of new things which had occurred in many minds when the rapid development of science seemed to threaten the very foundation of religion, and commerce was filling the world 
with the sordid greed of gain. In the "Palace of Art", he describes and condemns the spirit of aestheticism and Pre-Raphaeliticism, whose sole religion was the worship of beauty and knowledge for its own sake. "Maud" gives a dramatic rendering of the revolt of a cultured mind against the hypocrisy and corruptions of a society degraded by the worship of Mammon. In his "Idylls of the King", he has reduced the plan of the Arthurian stories to the necessities of Victorian morality. In "Memoriam", he traces the triumph of Faith and Love over Death and Skepticism. In all these ways, Tennyson represents the Victorian Age.

Like Pope and Tennyson, Chaucer represents his own Age. He is as truly the social chronicler of England in the late fourteenth century as Froissart is the political and military chronicler of France during the same period. His poetry reflects the fourteenth century not in fragments but as a complete whole. Other poets of his Age direct their gaze and attention to only a certain limited aspect of the age. For example Wyclif (1330-1408) reflects the fear produced in the wealthier class by the Peasant Rising; Barbour mirrors the break between the literature of Scotland and of England and the advent of patriotic Scottish poetry; and Langland (1330-1400) presents a picture of the corruption in the Church and the religious order. Each of these authors throws light only on one aspect of fourteenth century life. It is Chaucer's greatness that he directs his comprehensive gaze not on one aspect only of his Age but on all its wide and variegated life. He is the wide and capacious soul, and takes a fuller view of his times more than anyone else could have taken in those days. Chaucer gives us a direct transcription of reality and a true picture of daily life as it actually lives in most familiar aspects. Chaucer represents all this fully nowhere but in "Prologue to Canterbury Tales" in which through the presentation of the characters, Chaucer represents the wide sweep of English life by gathering a motley company together and making each class of society tell its own typical story.

Humour is the sympathetic appreciation of the comic, the faculty which enables us to love while we laugh. It is the humour which enables us to see the person's point of view, to distinguish between crimes and misdemeanours. Above all, it is humour which points out those enduring peculiarities, those little foibles and harmless weaknesses which give a character a warm place in our affections. There is no sting in humour, no consciousness superiority. On the contrary, it contains an element of tenderness. Obviously humour is distinct from satire, but it can be distinguished from farce and wit only insisting on the externals when speaking of them. Humour is indeed the soul of all comedy. Satire, being destructive, not constructive, is in a class apart, but even satire may become so softened by humour as it does in Chaucer that it may lose the 
element of caricature and serve only to give a keener edge to wit. Chaucer's whole point of view is that of the humorist. He is a comic poet who saunters gaily through life pausing the notice every trifle as he passes. He views the world as the unaccustomed traveller views a foreign country. He possesses the faculty of amused observation in a pre-eminent degree. Again and again he contrives to invest some perfectly trifling and commonplace incident with an air of whimsicality, and by so doing to make it at once realistic and remote.

Chaucer's humour, as has been acknowledged by almost every critic, in always sympathetic. In the Prologue, except in his handling of the Monk and the Friar there is no sting in it. As Legouis puts it Chaucer does not treat with disdain those whose foolishness he has fathomed, nor does he turn away in disgust from the rascal whose tricks he has detected. If humour can be defined as "the sympathetic appreciation of the comic", i.e. the faculty which enables us to laugh-_but to laugh affectionately and sympathetically, then Chaucer was indeed a great humorist. (Naeem, 2010)

Sing (2012) states that Irony, in its broadest sense, is a rhetorical device, literary technique, or event characterized by an incongruity, or contrast, between reality (what is) and appearance (what seems to be). Verbal, dramatic, and situational irony are often used for emphasis in the assertion of a truth. The ironic form of simile, used in sarcasm, and some forms of litotes can emphasize one's meaning by the deliberate use of language which states the opposite of the truth, denies the contrary of the truth, or drastically and obviously understates a factual connection. He further adds that Irony is effective because it prevents the author's work from becoming didactic. Since most works of fiction that employ irony tend to deal with serious issues, such as the hypocrisy in religion, society, or government, a more serious or realistic approach risks becoming pretentious. Irony, particularly satire, can be an effective way to not only approach such topics but do so in way that is humorous or entertaining (though it's important to point out that not all satire is funny). Another reason why irony is effective is because it allows readers to see the discrepancies the author is pointing out about humans or society. For instance, in Twelfth Night, audiences are able to witness the absurdities that Elizabethan society placed on decorum within courtship rituals and the ways those rituals are complicated by gender expectations.

Sitepu (2018) in McClennen (2011, 2011: 1-2)Satire serves as a comedic and pedagogic form uniquely suited to provoking critical reflection. Its ability to underscore the absurdity, ignorance, and prejudice commonly accepted behavior by means of comedic critical reflection offers an especially potent form of public critique, one that was much needed in the social environment. Sing (2012) states that Satire is the mind/wits; 
irony is the reasoning/rhetorical tool; humour is the substance. Satire is a genre of literature, and sometimes graphic and performing arts, in which vices, follies, abuses, and shortcomings are held up to ridicule, ideally with the intent of shaming individuals, and society itself, into improvement. Although satire is usually meant to be funny, its greater purpose is often constructive social criticism, using wit as a weapon and as a tool to draw attention to both particular and wider issues in society. A common feature of satire is strong irony and sarcasm-"in satire, irony is militant"-but parody, burlesque, exaggeration, juxtaposition, comparison, analogy, and double entendre are all frequently used in satirical speech and writing. This "militant" irony or sarcasm often professes to approve of (or at least accept as natural) the very things the satirist wishes to attack. Satire is nowadays found in many artistic forms of expression, including literature, plays, commentary, television shows, and media such as lyrics. Satire is a technique employed by writers to expose and criticize foolishness and corruption of an individual or a society by using humor, irony, exaggeration or ridicule. It intends to improve the humanity by criticizing its follies and foibles. A writer in a satire uses fictional character, which stands for real people to expose and condemn their corruption. A writer may point a satire toward a person, a country or even the entire world. Usually, a satire is a comical piece of writing which makes fun of an individual or a society to expose its stupidity and shortcomings. In addition, he expects that whosoever he criticizes improves his character by overcoming his weaknesses.

\section{Research Method}

Regarding the research method, having a focus on content analysis, qualitative research is used in performing this research. Sahu (2013: 4) says that in qualitative approach, research is mainly concerned with subjective assessment of the respondent. It is mainly concerned with attitudes, opinions, behaviors, impressions, etc. Thus, qualitative research is an approach to research to generate insights of the subject concerned in non-quantitative form or not subjected to rigorous quantitative analytical tools. Besides, this research uses descriptive method proposed by Kothari (2004) since it describes a state or an event that already exists, and is depicted in the novel. The purpose of this research is to reveal the redeeming evil of colonialism to Igbo people in Things Fall Apart by Chinua Achebe, who audaciously acknowledges that colonialism has brought positive impacts in terms of enlightenment, progress and divergent developments to the Nigerian Igbo so that the truth that colonialism contributes to the developments of the lower Niger is indisputable. 


\section{Discussion}

At the outset, it must be made clear that Chaucer at heart was a realist, and he revealed the truth about life as he saw it. Chaucer's realism primarily comes out in the setting of "The Canterbury Tales" which is not only his masterpiece among the poet's own works but also the high point of all English medieval literature. The pilgrimage belonging to all classes of society journeying from London to the holy shrine of St. Thomas at Canterbury provides Chaucer a fitting opportunity to present realistically the picture of the real world of fourteenth century life. Chaucer imparts the solid touch of realism in the portrayal of his characters. Each character with the dress, manner and behavior is highly conducive to realism. Chaucer presents the variegated life of his age faithfully and realistically.

Through the ecclesiastical characters in the Prologue to the Canterbury Tales, Chaucer constructs a representative picture of the condition of the church and its ministers in his age. He does not strike pointedly at the corruption among the clergymen of the times but he certainly presents realistically the fatty degeneration that had set in religious life of his age. The clergymen instead of devoting their time and energy to religious meditation have given themselves up to profligacy, and Epicureanism. Chaucer does not attack any principle or dogma of Christian Catholicism, but certainly he cannot tolerate the growing corruption, laxity of discipline and love of luxury prevailing among the clergy. He, therefore, satirises these depraved and fallen ecclesiastics of his times. A lot of humours in The Prologue springs from Chaucer's use of irony and satire. It is vivid in the The Prologue that most of the portraits in The Prologue are presented to us in a satirical light, though the satire is neither malicious nor scurrilous. Chaucer's satire is always mild and gentle. Chaucer is not prompted by either ill-will, spite, or cynicism. Nor does he become furious or indignant in his exposure of the follies and absurdities of the various characters. He never indulges in vituperation or denunciation. He lashes his victims not only gently but almost affectionately.

Chaucer's use of irony may first be noted in his presentation of the Prioress. The Prioress, we are told, spoke French fluently and elegantly, according to the school of Stratford-at-Bow (Parisian French not being known to her). This is an ironical reference to the Prioress's aristocratic pretensions. Her dress and her fashionable manners are also ironically described. She let no morsel all from her lips; and politely after her food she reached. She took pains to imitate the behaviour of the royal court. As for her charitable nature, Chaucer tells us that she would weep if she saw a mouse caught in a trap, that she fed her pets dogs with roasted meal, or milk and the finest bread 
(when vast numbers of people were not getting enough to eat), and that she felt greatly distressed if anybody struck one of her pet dogs with a stick. The inscription on the Prioress brooch was: "Love conquers all". There is irony even here, because love here seems to have an ambiguous meaning, love both in the divine and secular senses. In short, the ironic implication throughout the portrait of the Prioress is that, in spite of her holy calling, she is more concerned with worldly things than with the spirit. Chaucer emphasizes the Prioress's basic feminity, rather than her spiritual qualities, when he refers to her fine nose, small mouth, soft and read lips, eyes grey as glass, and so on. Her name too was Eglantine which was a heroine's name in the conventional romances. The effect of all this is an ironic association of the religion and the worldly, and the suggestion that the Prioress was more worldly than religious.

The Prioress bothers more about modish etiquette than austerity. This Prioress is essentially well-bred but she is also individualized. She has a romantic name, Eglantine. She indulges in certain vanities which belonged, either wholly or partly, to many nuns of Chaucer's time. A Prioress was not expected to swear at all, but Eglantine swears by Saint Loy, the seventh-century courtier-turned saint.

There was also a Nonne, a Prioress,

That of hir smyling was ful simple and coy;

Hire gretteste oath was but by saint Loy,

And she was cleped madame Eglentyne.

(Prologue: 118 - 121)

Besides, Nuns were also forbidden to keep pets of any kind but Eglantine possesses little dogs upon which she lavishes affection and care. She fed her pets dogs with roasted meat, or milk and the finest white bread (when vast numbers of people were not getting enough to eat), and that she felt greatly distressed if anybody struck one of her pet dogs with a stick.

Of smale houndes hadde she that she fedde

With rosted flesh or milk and wastel breed;

(Prologue: 146 - 147)

She cannot hide her love of jewellery. Her rosary is too elaborate or a nun, and the brooch she wears, bearing an ambiguous motto, should not be worn by a nun. There is also the inscription on the Prioress' brooch, that is: Amor vincit omnia "Love conquers all". There is irony here, because love here seems to have an ambiguous meaning, love both in the divine and secular senses. 
And ther-on heng a brooch of gold ful sheene,

On which ther was first write a crowned A,

And after Amor vincit omnia.

(Prologue: $160-162$ )

The Prioress indeed corresponds to the character of prioress as they were in the fourteenth century.

The Friar is a jolly beggar who employs his tongue to carve out his living. He is a representative of his class. He is a "limiter", that is, a friar who has secured the begging rights in a specified area. He knows how to induce all the women in that area to give him money or food in response to his "dalliance". He has a way with him. He knows all the latest songs, with which he entertains the fair wives with presents of ornamental knives and pins, and his initial blessing of each house he visits is pleasantly satisfying. When he visits richer or more important people, his manner changes; he becomes courteous and humble. He is only ready to hear confessions, and to sell absolution for money, which is, of course, his greatest sin. He will have nothing to do with lepers or with the poor. He will deal only with those who can be a source of profit to him.

For unto swich a worthy man as he

Acorded nat, as by his facultee,

To have with sike lazars aqueyntaunce;

It is nat honeste, it may nat avaunce,

For to deelen with no swich poraille;

But all with riche and sellers of vitaille.

And over al, ther as profit sholde arise,

Curteis he was and lowely of servyse:

(Prologue: $243-250$ )

The Monk too is portrayed satirically. This Monk was even worldlier than the Prioress, with nothing spiritual about him. Chaucer makes an abundant use of irony in describing the Monk's character. The Monk was fond of hunting and kept a large number of fine horses in his stable. When he rode, people could hear the jingling of the bells on the bridle of his horse. He never observed the rules of monastic discipline because, says Chaucer ironically, these rules were "old" and somewhat "strict" and because the Monk wanted old things to be forgotten and to embrace new customs. Continuing the irony, 
Chaucer says that the monk did not wish to drive himself mad by studying too much, and that he did not work with his hands because he did not see how the world could be served by St. Augustine's advice to the monks to perform manual labour. This Monk had, too, a gold pin with a love-knot in its large end. The irony here becomes evident when we recall that a monk was expected neither to possess gold ornaments not to think of love. The Monk is further exposed when we read that he was fond of eating a roasted fat swan. The most ironical line in the portrayal of the Monk is the one which says: Now certainly he was a fair prelate. This line is also a good example of Chaucer's tongue-in-cheek manner of writing. This Monk did not subscribe to the doctrine that a monk, who is neglectful of rules, is like a fish without water. The Monk also wore one the most expensive kind of fur on his sleeves.

The Monk is also satirically portrayed. The Monk is a fat well-fed individual who is more interested in hunting than in the performance of his religious duties. He neither labours with his hands nor pores over a book in the cloister. The Monk does not fast or deny himself costly garments; instead he loves a fat swan the best of any roast; he wears the finest gray for in the land, an elaborate gold pin in the shape of a love-knot, and costly supple boots. He owns greyhounds which are swift as birds, and in his stables are many valuable horses. Thus, Chaucer's Monk is a lively representative of his class.

A Monk ther was, a fair for the maistrie.

An outridere, that lovede venaire

Ful many a deyntee hors hadde he instable;

(Prologue: 118 - 121).

Next comes the Friar who is treated in the same ironical and satirical manner. This Friar was adept (skillful) in gossip and the use of flattering language. We notice the keen irony when we are told that he had performed many marriages of young women at his own cost. (The implication, of course, is that he had seduced many young women or kept them as his mistresses before he married them off at his own cost). The irony becomes even keener when we are told that he was "a noble pillar of his order" (which reminds us of the Monk being "a fair prelate"). The Friar heard confessions, and pleasant was his absolution. Continuing his tongue-in-cheek manner, Chaucer tells us that the Friar believed that a sinner was truly repentant if he gave enough money to a priest as a token of his repentance. The Friar said that sinners, instead of weeping and offering prayers, should give silver to the poor friars. He carried knives and pins and other ornamental articles which he gave to beautiful women. He had a merry voice, could 
sing well, and could play on the fiddle. Physically, he was as strong as a champion. He knew every innkeeper and every bar-maid but hardly went near a leper or a beggar. Some of Chaucer's sharpest irony appears in the lines in which he says that the Friar was such a worthy man that it was not proper for him, in view of his position or status, to become acquainted with sick lepers because a man like him should deal not with poor people who could afford to give him nothing, but with the rich and the sellers of food. He was courteous and humble in his service wherever he found a possibility of monetary profit. The irony in this portrait reaches its climax in the following line: there was no man anywhere so virtuous. But this line does not mark the end of this satirical portrait. Chaucer goes on to say that the Friar's reading of the Gospel was so pleasant that he would manage to obtain some little money even from a destitute widow. He obtained money also from the litigants by acting as an arbitrator on love-days. In portraying the Friar, Chaucer strips him completely naked, exposing him to ridicule. Nowhere does Chaucer criticize him directly. His criticism is conveyed to us ironically. We can infer that Chaucer here maintains the Friar's humanity and even his liability, despite his corruption and moral laxity; this he does in the last few lines of the portrait where the Friar is associated with song and music.

In exposing the sins of the Summoner and the Pardoner, Chaucer is almost merciless, though even here he is not spiteful or savage. There is plenty of satire in these two portraits. Thus, the Summoner had a fire-red face on which were pimples that could not be cured by any medicine. He was hot, and lecherous as a sparrow. When he had drunk wine heavily, he would keep repeating the few Latin words and phrases which he had memorized. Here is an example of Chaucer's satirical writing:

But whose koude in oother thyng hym grope,

(But if anyone questioned him on anything else).

Thanne hadde he spent at hisphilosophie;

(Then he had exhausted all his learning).

Ay "Questio quid juris" wolde he crie

(Constanly "Questio quid juris" would he cry).

The fun here results from the way Chaucer exposes the shallowness of the Summoner's knowledge of Latin. The satire continues in the lines which tell us that the Summoner would, for a quart of wine, allow a good fellow to keep a mistress for twelve months. The Summoner could also take advantage of a girl. In a sarcastic manner, Chaucer says that the Summoner was a gentle rascal and a kind one, and that a better 
companion than he could not be found. Chaucer then satirizes the Summoner's love of money. The Summoner would tell people that they should not feel afraid of the arch-deacon's curse (that is, excommunication) because, by paying money, they could easily rid themselves of the curse. As a final touch of satire, the Summoner's headgear is described as being large like an ale-house sign, and his buckler being a huge loaf of bread. These symbols of physical appetite do not suggest robust health (as with the Franklin) but appetite which runs to gluttony.

Chaucer's freedom from malice towards his fellows is nowhere more plainly shown than in his physical description and characterization of the Summoner. This pimpled, scurfy, scraggy-bearded, lecherous, drunken wretch, this foul-breathing ignorant swindler, whose hideous aspect terrified children but who yet had jurisdiction over all young people in the diocese, still does not tempt the poet to moralize. In fewer than fifty lines, he exposes him body and soul as mercilessly as Swift or Aldous Huxley might have done in a far larger space of prose. Unlike these later satirists, however, Chaucer does not consume himself in a frenzy of hatred and disgust. Nevertheless, his satire bites home at least as powerfully as theirs.

There is plenty of ironical humour in the portrait of the Pardoner. We are told that this Pardoner had come straight from the court of Rome, that his bad was "brimful of pardons, come from Rome all hot", and that in his occupation "there was not another such pardoner" from one end of England to the other. These are examples of irony at its best because the Pardoner is here exposed to ridicule for his frauds. He is further satirized when we are told that he carried a pillow-case which he said was the Virgin's veil, a small piece of canvas which he claimed to be a piece of the sail of St. Peter's boat, and a glass containing pigs' bones which were supposed to be bones of saints. With these relics he made more money from the simple people of a parish in one day than the parish priest got in two months.

The Summoner is basically wicked. He teaches a sinner not to feel afraid of the archdeacon's curse because money, he says, will set everything right. The Summoner has all the young people of the parish under his thumb as he knows their secret and acts as their advisor. The Summoner will readily excuse a fellow or keeping a mistress for a year, if he is given only a quart of wine. He is sexually immoral himself, because he can take advantage of a girl; that is he will seduce a girl, if he gets the opportunity.

As hoot he was, and lecherous, as sparwe,

(Prologue: 626)

A better felawe sholde men noght fynde. 
He wolde suffree, for a quart of wyn,

A good felawe to have his concubyn

A twelf monthe, and excuse hym atte fulle;

And prively a finch eek koude he pulle.

(Prologue: $648-652$ )

It is clearly noticed that the Summoner is a depraved fellow. He will excuse a fellow fully for the sin of keeping a mistress for a year only for a quart of wine. It also fully signifies that he loves to drink wine.

The Pardoner, who is the Summoner's friend and comrade, is a despicable parasite trading in letters of pardon with the sinners who could ensure a seat in heaven by paying hard cash. The Pardoner, we are told, has come straight from the papal court at Rome, and he bears a bag full of pardons. The Pardoner carries with him, as relics, a pillow case which he claims to be part of the Virgin Mary's veil, and a piece of cloth which he claims to be part of the sail of St. Peter's boat. He also has a cross made of brass but studded with gems, and some pig's bones which he claims to be a saint's relics. He well knew how he must preach and speak in a biting tone in order to obtain money from the congregation.

For wel he wiste, whan that song was songe,

He moste preche, and wel affile his tonge

To wynne silver, as he full wel koude,

(Prologue: 711 - 713)

The Clerk and the Parson, as has already been said above, are worthy of respect and admiration. The Clerk is a devoted student of logic, and he would rather have twenty volumes of Aristotle than rich robes or a fiddle. His outer coat is threadbare for he is poor, even his horse is as lean as a rake. What money he receives from his benefactors, he spends on books and learning, and he repays the benefactors by heartfelt prayers for their souls.

But all that he myghte of his freendes hente

On bookes and his lernynge he it spente,

And bisily gan for the soule preye

Of hem that yaf hym wher-with to scoleye,

(Prologue: 299 - 302) 
He never displays unseemly levity in behaviour. He does not speak one word more than is necessary; when he does speak, he is brief, to the point, and always noble in his meaning. He is glad to learn and glad to teach.

Noght o word spak he moore than was neede,

And that was seyd in forme and reverence

And short and quyk and ful of hy sentence

Sownynge in moral vertu was his speche

And gladly wolde he lerne and gladly teche.

(Prologue: 304 - 308)

The Parson is apparently a follower of Wyclif who revolted against the corruption of the church. He is a learned man faithfully preaching Christ's gospel and devoutly instructing his parishioners. He emphasizes two facts: if gold rusts, iron will do far worse; and if the shepherd is foul, the sheep cannot be clean.

That If gold ruste what shal iron do?

For if a preest be foul, on whom we truste,

No wonder is a lewed man to ruste;

And shame it is, if a prest take keepe,

A shiten shepherde and a clene sheepe.

(Prologue: 497 - 451)

$\mathrm{He}$ is holy and virtuous, meek and polite. He is no hireling but a worthy shepherd to his flock. The Parson will not leave his parishioners "to sink in the mire", in order that he may make more money by running off to London to become a chantry priest or to seek a position in some guild: "he was a shepherd and noght a mercenaire". Although he is good, he does not hesitate to reprimand anyone who shows no repentance. He treats those of high or low position in exactly the same way.

But if were any persone obstinate,

What so he were, of high of lough estat

Hym wolde he snybben sharply for the nonys.

(Prologue: 521 - 523) 


\section{Conclusion}

Prologue to the Canterbury Tales gives us a fairly authentic and equally extensive picture of the medieval religious officials prevailing in England. The religious officials belong to the pilgrims of various ranks and types. The higher and more prosperous ones include an aristocratic and rather affected Prioress, a Monk addicted to horses and "venery" (hunting), a Friar adept in persuasion and seduction, a Canon of religion who joins the party and route with an attendant Yeoman, and a Pardoner who makes a good living by selling indulgences (pardons granted by a priest for cash payment) and fake relics of saints. Humbler members of the clergy are a Nun, at least one Priest journeying with the Prioress, and a country Parson who, in contrast to the Monk, the Friar, and the Pardoner, represents the type of un-mercenary, hard-working priest of humble origin obviously admired by Chaucer. The Clerk of Oxford, still a student, is also a sincere devotee of his profession.

\section{References}

[1] Chaucer, Geoffrey. (1996). The Canterbury Tales. Middlesex: Penguin Books Ltd.

[2] Chaucer, Geoffrey. (e.d.) Robinson F. N. (2000). The Prologue to the Canterbury Tales. London: Oxford University Press.

[3] Creswell, John W. (2014). Research Design: Qualitative, Quantitative, and Mixed Methods Approaches, Fourth Edition. United States of America, California: Sage Publications Inc.

[4] Kothari, C. R. (2004). Research methodology: methods and technique. Jaipur, India: New Age International (P) Limited, Publishers.

[5] Lall, Ramji. (2001). The Prologue. New Delhi: Rama Brothers.

[6] Mindra, S. C. (2001). English Literature for Competitive Examinations. Bareilly: Raza Barqui Press.

[7] Naeem, Muhammad. (January 10, 2018). Humor, Satire and Irony in the Prologue. Retrieved from http://neoenglishsystem.blogspot.co.id/2010/09/humour-satire-andirony-in-prologue.html

[8] Sahu, Pradip Kumar. (2013). Research methodology: a guide for researchers in agricultural science, social science and other related fields. India: Springer.

[9] Sing, Raj Kishor. (2012). Humour, Ironi and Satire in Literature. International Journal of English and Literature (IJEL). Nepal: Kathmandu: 3(4), 65-72

[10] Sing, T. (1999). A History of English Literature. Bareilly: Student Store. 
[11] Sitepu, Darman, Sahri, Zulfan, and Siregar, Amrin. (2018). "Satire on Capitalism in Bertold Brecht's Caucasian Chalk Circle" in The 1st Annual International Conference on Language and Literature, KnE Social Sciences, pages 167-177. DOI 10.18502/kss.v3i4.1929. Retrieved from https://knepublishing.com/index.php/ Kne-Social/article/view/1929/4314 on 7 July 2018. 